\title{
Research on the Selection of Strategic Environment Analysis Models for Power Enterprises
}

\author{
Haixu Song ${ }^{1, *}$ \\ ${ }^{1}$ Dept. of Corporate Strategy, State Grid Energy Research Institute Co., Ltd, 102209, Beijing, China
}

\begin{abstract}
The paper analyses the advantages, shortcomings and applicability of the enterprise strategic environment analysis model. In addition, it analyses the characteristics of power enterprises which are different from ordinary enterprises. Based on this, the paper proposes the appropriate models which power enterprises should be selected. The study indicates that power companies are suitable to be used the PEST model as the basic method, while using the ecosystem analysis model and the environmental uncertainty analysis model as a supplement, so as to conduct comprehensive application and judgment.
\end{abstract}

\section{Introduction}

At present, the energy revolution, industrial revolution, and technological revolution are accelerating. The international environment becomes more and more instability and uncertainty. The situation faced by energy and power companies is complex than before[1]. Power companies should analyze the situation in depth, adapt to the environment changes, and improve their core competitiveness. There are many strategic environment analysis models, but because power companies have different characteristics from ordinary companies, we should choose the appropriate ones analysis. Therefore, this paper analyses the advantages, shortcomings and applicability of the corporate strategic environment analysis model, and combines the characteristics of power companies to choose the most appropriate models, which could provide reference for strategic analysis of power companies.

\section{Analysis on the Characteristics of the Enterprise Strategic Environment Analysis Models}

The corporate strategic environment analysis models commonly used include PEST analysis model, Michael Porter's five forces model, ecosystem analysis model, EFE matrix model, and environmental uncertainty analysis model. Through analysis, it is found that different models have different characteristics. Analyzing the strengths and weaknesses of each model is the basis for selecting and using them properly.

\subsection{Characteristics of PEST analysis model}

The PEST analysis model is a research tool for analyzing the companies' macro environment. $\mathrm{P}$ represents the political environment. E represents the economic environment. $\mathrm{S}$ represents the social environment. $\mathrm{T}$ represents the technological environment. We always study the macro situation facing the enterprise through these four factors[2].

The political environment mainly refers to a country's political system, government policies, laws and regulations, etc. Different countries have different social characteristics, and different social systems have different restrictions and requirements on organizational activities. The economic environment refers to the characteristics and development direction of the economy in which enterprises participate in competition Generally speaking, companies are more willing to compete under economic conditions with high growth potential. The social environment is related to social attitudes and values. Social and cultural factors are the driving force to promote changes in population, economy, politics, technology and other factors. The changes in social and cultural factors could propose challenges to enterprises. The technological environment refers to the technological level, technological policies, new product development capabilities, and technological development trends of the countries and regions. Because of the rapid pace of technological change, companies must comprehensively research technological factors. Generally speaking, the sooner the new technology is adopted, the more likely the company will obtain a higher market share and higher returns.

The advantages of the PEST analysis model are: 1) It can comprehensively analyze the external environment faced by companies, and ensure the feasibility of the company's strategic planning from a macro perspective. 2) Companies can capture opportunities and perceive threats according to the environment change. The disadvantages are: 1) It is difficult to determine the environment and its impact for diversified business enterprises. 2) The analysis result is uncertain, and it is difficult to describe

*Corresponding author: shxstudent@126.com 
the different importance of every influence factors. 3) It does not provide the evaluation criteria, so the analysis results depend on the experts' ability, which has much subjectivity and uncertainty. Generally, the PEST model is more suitable for strategy analysis at the corporate group level, or combined with other models as a basic analysis.

\subsection{Characteristics of Michael Porter's five forces model}

Michael Porter's five forces model considers that there are five forces in the industry that determine the competition degree and affect the competitive strategic decisions of existing companies[3]. The five forces are the bargaining ability of suppliers, the bargaining ability of buyers, the competitiveness of existing competitors, the threat of new entrants, and the threat of substitutes. The bargaining ability of suppliers refers to the capacity of suppliers to increase the price of input factors and reduce the quality of unit value. The bargaining ability of buyers refers to the capacity of buyers to reduce price and demand higher product quality. The competitiveness of existing competitors refers to the competitiveness of the competitors in terms of products, prices, marketing, and services. The threat of new entrants means that while new entrants will bring new production or new resources to the industry, they will hope to win a place in the market, which will eventually lead to a decline in the market share and profitability of existing companies. The threat of substitutes means that two companies in the same industry or in different industries may compete with each other because the products they produce are substitutes for each other[4].

The advantages of Michael Porter's five forces model are: 1) It takes a large number of different factors together in a simple model to make the analysis on the basic competitive situation of an industry easy. 2) The five main sources of competition are determined, which can help companies judge their own position in the entire industry. The disadvantages are: 1) It analyzes problems from the perspective of static market, which is limited in accuracy and may not keep up with market changes. 2) It is not suitable for non-profit organizations, such as public service units. 3) It is a bit one-sided. Suppliers and new entrants are not all the opposites of enterprises, because sometimes they may become business cooperators. Generally, Michael Porter's five forces model is more suitable for industry environment analysis, especially companies in competitive industries.

\subsection{Characteristics of ecosystem analysis model}

Ecosystem theory considers that the corporate strategy making is not only a process in which the company adapts to the external environment, but also a process of mutual growth with the external environment and other stakeholders. So the corporate ecosystem is an economic group formed by interacting corporate organizations and individuals, which generally includes manufacturers, sellers, consumers, suppliers, investors, competitors, business owners or shareholders, and relevant government agencies, etc. And it includes all kinds of resources needed by the enterprise's production and operation.

The advantages of the ecosystem system analysis model are: 1) It has strong integrity. It can organically link the enterprise with external environment. 2) It has strong hierarchy. It can help enterprises analyze the environmental composition, environmental characteristics and impacts form different levels. The disadvantages are: 1) It's relatively complex, especially for diversified companies. 2) The requirements for analysts are relatively high. Analysts should have very indepth understanding of the company and its related parties. Generally, ecosystem analysis model is suitable for the companies that have many related parties in the upstream and downstream industry chain. The company can use ecosystem system analysis take in-depth analysis when the competition and cooperation relationship are complicated.

\subsection{Characteristics of EFE matrix model}

The EFE matrix is called the External Factor Evaluation Matrix, which is a tool for analyzing the external environment. It finds the key factors that could affect a company's future development and evaluate the degree from opportunity and threat. Then it determines the weight according to the influence degree of each factor, and finally calculates the total weighted score of the company.

The advantages of the EFE matrix model are: 1) The final analysis result is objective numbers, which is convenient for comparison. 2) According to the analysis results, companies can obtain their own ability to grasp opportunities or respond to threats, which is conducive to the formulation or adjustment of strategic planning. The disadvantages is that the selection of affecting factors, the evaluation of weight and score are all quite subjective. And it has a great influence on the results. Generally, the EFE matrix model is suitable for the quantitative analysis to evaluate the company's ability to grasp opportunities or respond to threats.

\subsection{Characteristics of environmental uncertainty analysis model}

The environmental uncertainty analysis model measures environment from two aspects: one is the complexity of the environment, the other is the dynamic nature of the environment.

The advantage of the environmental uncertainty analysis method is that it can analyze the uncertainty of the environment through the complexity and dynamics. And it can provide evidence for companies' strategy formulation to reduce the strategic risk. The disadvantages are: 1) The environment faced by enterprises cannot be clearly classified into one of the four categories, and is often between two different situations. 2) As the environment changes, the simple and complex, the stable and dynamic may be transformed. Generally, 
the model is suitable for the uncertainty analysis of the environment.

Table1. The characteristics of enterprise strategic environment analysis models

\begin{tabular}{|c|c|c|c|}
\hline Model & Advantages & Disadvantages & $\begin{array}{c}\text { Applicabilit } \\
\mathbf{y}\end{array}$ \\
\hline $\begin{array}{l}\text { PEST } \\
\text { analysi } \\
\mathrm{s} \\
\text { model }\end{array}$ & $\begin{array}{l}\text { 1) Analyse } \\
\text { external } \\
\text { environment } \\
\text { Comprehensi } \\
\text { vely. } \\
\text { 2) Capture } \\
\text { opportunities } \\
\text { and perceive } \\
\text { threats }\end{array}$ & $\begin{array}{l}\text { 1) Be difficult } \\
\text { to determine } \\
\text { environment } \\
\text { and its impact } \\
\text { for diversified } \\
\text { business } \\
\text { enterprises. } \\
\text { 2) Analysis } \\
\text { result is } \\
\text { uncertain. } \\
\text { 3) It does not } \\
\text { provide the } \\
\text { evaluation } \\
\text { criteria. }\end{array}$ & $\begin{array}{l}\text { Be suitable } \\
\text { for strategy } \\
\text { analysis at } \\
\text { corporate } \\
\text { group level, } \\
\text { or combined } \\
\text { with other } \\
\text { models as a } \\
\text { basic } \\
\text { analysis. }\end{array}$ \\
\hline $\begin{array}{l}\text { Michae } \\
1 \\
\text { Porter's } \\
\text { five } \\
\text { forces } \\
\text { model }\end{array}$ & $\begin{array}{l}\text { 1) Make the } \\
\text { analysis on } \\
\text { the industry } \\
\text { competitive } \\
\text { situation } \\
\text { easy. } \\
\text { 2) Help } \\
\text { companies } \\
\text { judge their } \\
\text { own position } \\
\text { in the entire } \\
\text { industry. }\end{array}$ & $\begin{array}{l}\text { 1) Be limited in } \\
\text { accuracy and } \\
\text { may not keep } \\
\text { up with market } \\
\text { changes. } \\
\text { 2) It is not } \\
\text { suitable for } \\
\text { non-profit } \\
\text { organizations. } \\
\text { 3) It is a bit } \\
\text { one-sided. }\end{array}$ & $\begin{array}{l}\text { Be suitable } \\
\text { for industry } \\
\text { environment } \\
\text { analysis, } \\
\text { especially } \\
\text { companies in } \\
\text { competitive } \\
\text { industries. }\end{array}$ \\
\hline $\begin{array}{l}\text { Ecosyst } \\
\text { em } \\
\text { analysi } \\
\text { s } \\
\text { model }\end{array}$ & $\begin{array}{l}\text { 1) Strong } \\
\text { integrity. } \\
\text { 2) Strong } \\
\text { hierarchy. }\end{array}$ & $\begin{array}{l}\text { 1) Be relatively } \\
\text { complex, } \\
\text { especially for } \\
\text { diversified } \\
\text { companies. } \\
\text { 2) } \\
\text { Requirements } \\
\text { for analysts are } \\
\text { relatively high. }\end{array}$ & $\begin{array}{l}\text { Be suitable } \\
\text { for } \\
\text { companies } \\
\text { that have } \\
\text { many related } \\
\text { parties in } \\
\text { upstream and } \\
\text { downstream } \\
\text { industry. }\end{array}$ \\
\hline $\begin{array}{l}\text { EFE } \\
\text { matrix } \\
\text { model }\end{array}$ & $\begin{array}{l}\text { 1) Be } \\
\text { convenient } \\
\text { for } \\
\text { comparison. } \\
\text { 2) } \\
\text { Companies } \\
\text { can obtain } \\
\text { their own } \\
\text { ability to } \\
\text { grasp } \\
\text { opportunities } \\
\text { or respond to } \\
\text { threats. }\end{array}$ & $\begin{array}{l}\text { The selection of } \\
\text { affecting } \\
\text { factors, } \\
\text { evaluation of } \\
\text { weight and } \\
\text { score are all } \\
\text { quite subjective. }\end{array}$ & $\begin{array}{l}\text { Be suitable } \\
\text { for the } \\
\text { quantitative } \\
\text { analysis to } \\
\text { evaluate the } \\
\text { company's } \\
\text { ability to } \\
\text { grasp } \\
\text { opportunities } \\
\text { or respond to } \\
\text { threats. }\end{array}$ \\
\hline $\begin{array}{l}\text { Enviro } \\
\text { nmenta } \\
1 \\
\text { uncerta } \\
\text { inty } \\
\text { analysi } \\
\text { s } \\
\text { model }\end{array}$ & $\begin{array}{l}\text { It can analyse } \\
\text { the } \\
\text { uncertainty } \\
\text { of the } \\
\text { environment } \\
\text { through the } \\
\text { complexity } \\
\text { and } \\
\text { dynamics. }\end{array}$ & $\begin{array}{l}\text { 1) Not all the } \\
\text { environment } \\
\text { can be clearly } \\
\text { classified into } \\
\text { one of the four } \\
\text { categories. } \\
\text { 2) As the } \\
\text { environment } \\
\text { changes, the } \\
\text { simple and } \\
\text { complex, the } \\
\text { stable and } \\
\text { dynamic may } \\
\text { be transformed. }\end{array}$ & $\begin{array}{l}\text { Be suitable } \\
\text { for the } \\
\text { uncertainty } \\
\text { analysis of } \\
\text { the } \\
\text { environment. }\end{array}$ \\
\hline
\end{tabular}

\section{Selection for Strategic Environment Analysis Model of Power Enterprises}

Power companies are related to the national economy and people's livelihood, and play an important role in the country's economic and social development. Power companies have unique characteristics that are different from other companies.

1) The scale of assets is large. Power companies are typical asset-intensive companies, and fixed assets occupy a large proportion of corporate assets. Because power projects often have huge investment amounts and long investment cycles, the size of the project has a significant impact on economic benefits. Therefore, power companies have strong economies of scale. Moreover, the larger the scale of a power company, the higher its safety, stability, and economy.

2) Industry chain is long. The power system covers multiple links such as power generation, transmission, distribution, power sales, and power consumption. Therefore, the power industry has a long industrial chain, and power companies involve many related units or institutions, such as power generation companies, power grid companies, power equipment companies, exploration and design companies, construction companies, as well as governments, corporate users, and residential users.

3) Industry barrier is high. Power is different from ordinary commodities in that their production, sales and use are integrated, and power generation, transmission, distribution and transformation are carried out simultaneously. Therefore, the power enterprise is a large industrial system that is more complex than ordinary manufacturing industry, accompanied by complex physical and chemical reactions and the transformation and transfer of matter and energy. So power companies have strong expertise and high industry barrier.

4) The geographical distribution is wide. Electricity is an important means of production and living. Electricity services cover every industry, enterprise and family in the whole society. Therefore, power companies cover all regions of the country, such as cities and villages, coastal areas and inland areas.

Because of the above characteristics of power companies, PEST analysis model, ecosystem analysis model, and environmental uncertainty analysis model are more suitable, while the Michael Porter's five forces model and EFE matrix model are not suitable for power companies.

1) The PEST analysis model is suitable for analyzing the macro-environment of power enterprises. Power companies are the supporting industries of the national economy and belongs to utility companies. They will be affected by multiple factors such as politics, economy, society, natural conditions, and technology, etc. The PEST model contains comprehensive and systematic environmental factors, so it is appropriate to use it as the basic model for strategic environment analysis of power companies.

2) Ecosystem analysis model is more suitable than Michael Porter's five forces model to analyze the industry environment of power companies. Power companies are 
not a completely competitive industry. It involves many stakeholders, and the relationship among them is relatively complicated. The relationship between upstream and downstream companies is close, and competitors and collaborators are intertwined. Therefore, it is difficult to analyze industry environment with Porter's five forces model. In contrast, the ecosystem analysis model can reflect the relationship between various stakeholders in the power industry ecosystem better, so it is more suitable.

3) The environmental uncertainty analysis model is suitable for the dynamic environment analysis of power companies when the external environment changes greatly. The environmental uncertainty analysis model can be used to judge the complexity of the environmental change.

On the whole, power companies are suitable to be used the PEST model as the basic method, while using the ecosystem analysis model and the environmental uncertainty analysis model as a supplement, so as to conduct comprehensive application and judgment.

\section{Conclusion}

The paper analyzes the advantages, shortcomings and applicability of the enterprise strategic environment analysis model. In addition, it analyses the characteristics of power enterprises which are different from ordinary enterprises. Based on this, the paper proposes the appropriate models which power enterprises should be selected. The study indicates that power companies are suitable to use the PEST model as the basic method, while using the ecosystem analysis model and the environmental uncertainty analysis model as a supplement, so as to conduct comprehensive application and judgment.

\section{Acknowledgement}

This research was financially supported by the SGCC Technology Project- The research on integrated simulation method and practical technology of think tank research platform.

\section{References}

1. J. Wen. Analysis on the Strategic Environment of New Energy Enterprises. Modern Business, 4(2017)

2. Y. M. Xi. Analysis of the External Environment of Enterprises. Higher Education Press, Beijing. (2001)

3. Q. J. Ge, H.J. Xiao. A Review of the Theoretical Research of Competitive Strategy Based on Environment. Business Review, 7 (2008)

4. E. P. Michael. Competitive Strategy. Huaxia Press, Beijing. (2005) 